Amasya Ilahiyat Dergisi - Amasya Theology Journal

ISSN 2667-7326 | e-ISSN 2667-6710

Aralık / December 2020, 15: 493-516

\title{
Organ Bağışı Tutumları ve Dindarlık İlişkisi
}

\author{
Sezai KORKMAZ \\ Dr. Öğr. Üyesi, Kahramanmaraş Sütçü İmam Üniversitesi, İlahiyat Fakültesi, \\ Din Psikolojisi Anabilim Dalı \\ Assistant Professor, University of Kahramanmaraş Sütçü İmam, Faculty of \\ Theology, Department of Psychology of Religion \\ Kahramanmaraş, Turkey \\ kzsezai@gmail.com \\ orcid.org/0000-0003-0250-6673
}

Makale Bilgisi / Article Information

Makale Türü / Article Types: Araştırma Makalesi / Research Article

Geliş Tarihi / Received: 04 Eylül / September 2020

Kabul Tarihi / Accepted: 05 Ekim / October 2020

Yayın Tarihi / Published: 30 Aralık / December 2020

Yayın Sezonu / Pub. Date Season: Aralık / December

Sayı / Issue: 15 Sayfa / Pages: 493-516

Atıf / Cite as: Korkmaz, Sezai. "Organ Bağışı Tutumları ve Dindarlık İlişkisi [The Relationship between Organ Donation Attitudes and Religiosity]". Amasya Ilahiyat Dergisi-Amasya Theology Journal 15 (December 2020): 493-516.

https://doi.org/10.18498/amailad.790564.

İntihal / Plagiarism: Bu makale, en az iki hakem tarafından incelendi ve intihal içermediği teyit edildi. / This article has been reviewed by at least two referees and scanned via a plagiarism software.

Copyright (c) Published by Amasya Üniversitesi, İlahiyat Fakültesi / Amasya University, Faculty of Theology, Amasya, 05100 Turkey. All rights reserved. https://dergipark.org.tr/amailad. 
494 | S. KORKMAZ / Organ Bağışı Tutumları ve Dindarlık İlişkisi

\section{The Relationship between Organ Donation Attitudes and Religiosity}

\section{Abstract}

Organ donation is below the expected number of cadaver donors (ppm) per million population in the world. The country with the highest number of cadaver donors per million in the world is Spain. In 2019, it was determined the number of cadaver donors per million as 48,9 in Spain. At the same year, in Turkey, the number of cadaver donors per million was determined as 7,54. There are many reasons why number of cadaver donors in Turkey is low. Main reasons are religious ground and insufficient knowledge. A large number of studies, the major factor for determining the attitudes towards organ donation is seem to be religion and religiosity. With the religiosity level of people in Turkey, the attitudes towards organ donation are becoming more important. For this reason, there is a need in literature for new studies that related to the relation between organ donation and religion. Therefore, the aim of this research is to fill the gap on the relation religiosity among organ donation in the literature. Under the guidance of studies dealing with the relationship between individual religion, religious practices and organ donation attitudes, the following hypotheses were tested: 1 . The attitudes towards organ donation differentiated by gender. 2. The religious practices and individual religiosity differentiated by gender. 3. There is a positive correlation between the dimension of benevolence \& moral values/belief values, and religious practices \& individual religiosity. 4 . There is a negative correlation between the dimension of benevolence \& moral/belief values, and fear of medical neglect \& bodily injury. 5. Religious practice predicts the values of benevolence, moral/belief values, fear of medical neglect, and fear of bodily injury. 6 . Individual religiosity predicts the values of benevolence, moral/belief values, fear of medical neglect, and fear of bodily injury. 7. The value of benevolence and the dimension of moral/belief values predict both the fear of medical neglect and bodily injury.

In this study, religiosity and the attitudes towards organ donation was examined. Religiosity was examined as religious practices and individual religion. The attitudes towards organ donation have two aspects called as positive and negative. The positive aspect of attitudes towards organ donation consists of the value of charity and moral/belief, at the same time the negative aspect of it consists of the fear of medical neglect and bodily injury.

The sample of research consisted of 205 (M: 26,3\%, F: 73,7\%) university students. The average age of the participants was determined to be 21.56 . In this research, the scale of attitudes towards organ donation, the scale of religiosity 
practices and the inventory of individual religiosity were used to measure the variable of religiosity. The scale of attitudes towards organ donation was developed by Parisi and Katz. The scale of religious practices was developed by Ayten and the inventory of individual religiosity was developed by Zagumny et al. The scales used in the study were statistically reliable and validity.

In this study's results, it was seen that a statistically significant level of differentiation was found in the dimension of bodily injury fear, which represents the negative level of attitudes towards organ donation by gender. Moreover, the level of religious worship was also differated by gender. In the considering the relations, the individual religiosity was correlated with the values of benevolence and moral/belief. Additionally, a significant correlation was also found between the sub-dimensions of attitudes toward organ donation. In study, it was also found that there was a statistical regression relation between individual religiosity and sub-dimension of attitudes towards organ donation which are the value of benevolence and moral/belief. According to the findings of this study, it is possible to say that the dimension of benevolence and moral/belief values that constitute the positive aspect of the attitudes towards organ donation were negatively regression relations with the fear of medical neglect and bodily injury that constitute the negative aspect of attitudes towards organ donation.

Keywords: Psychology of Religion, Organ Donation Attitudes, Religiosity, Religious Practices, Individual Religion.

Öz

\section{Organ Bağışı Tutumları ve Dindarlık İlişsisi}

Dünyada organ bağışı, milyon başına düşen kadavra donör sayısı (pmp) olarak beklenilenin altında seyretmektedir. Dünyada milyon başına düşen kadavra donör sayısı en fazla olan ülke İspanya'dır. 2019 yılında, İspanya'da milyon başına düşen kadavra donör sayısı 48,9 olarak tespit edilmiştir. Türkiye'de ise 2019 yılında milyon başına düşen kadavra donör sayısı 7,54 olarak belirlenmiştir. Ülkemizdeki organ bağışçı sayısının düşük olmasının altında birçok neden yatmaktadır. Dini gerekçelerle organ bağışı yapılmaması ve bu konuda yeteri kadar bilinçli ve bilgili olunmaması en başta gelen nedenlerdendir. Yapılan çalışmalara bakıldığında organ bağışı tutumlarında dindarlık veya din belirleyici ve büyük bir etken olarak görülmektedir. Ülkemizdeki dindarlık oranı değerlendirildiğinde organ bağışı tutumlarına yönelik davranışlar daha da önem kazanmaktadır. Bu nedenle literatürde din ile organ bağışı ilişkisini araştıran çalışmalara ihtiyaç duyulmaktadır. Bu 
496 | S. KORKMAZ / Organ Bağışı Tutumları ve Dindarlık İlişkisi

çalışmanın yapılma amacı literatürdeki dindarlık ile organ bağışı arasındaki ilişkiye yönelik ihtiyacı karşılamaktır. Buna bağlı olarak araştırmada şu hipotezler test edilmiştir: 1. Cinsiyete göre organ bağışı tutumlarında farklılaşma vardır. 2. Cinsiyete göre dini ibadet ve bireysel dindarlıkta farklılaşma vardır. 3. Yardımseverlik ve ahlak/inanç değerleri boyutu ile dini ibadet ve bireysel dindarlık arasında pozitif yönde korelasyon ilişkisi bulunmaktadır. 4. Yardımseverlik ve ahlak/inanç değerleri boyutuyla tıbbi ihmal korkusu ve bedensel yaralanma korkusu arasında negatif yönde ilişki vardır. 5. Dini ibadet, yardımseverlik ve ahlak/inanç değerlerini, tıbbi ihmal korkusunu ve bedensel yaralanma korkusunu yordamaktadır. 6. Bireysel dindarlık, yardımseverlik ve ahlak/inanç değerlerini, tıbbi ihmal korkusunu ve bedensel yaralanma korkusunu yordamaktadır. 7. Yardımseverlik ve ahlak/inanç değerleri boyutu, tıbbi ihmal korkusu ve bedensel yaralanma korkusunu yordamaktadır.

$\mathrm{Bu}$ çalışmada dindarlık ile organ bağışı tutumları arasındaki ilişkiler incelenmiştir. Dindarlık, bireysel dindarlık ve dini ibadetler olarak iki ayrı değişken olarak ele alınmıştır. Organ bağışı tutumlarının ise pozitif ve negatif olmak üzere iki yönü bulunmaktadır. Organ bağışı tutumunun pozitif yönünü; yardımseverlik ve ahlak/inanç değerleri, negatif yönünü ise tıbbi ihmal korkusu ve bedensel yaralanma korkusu temsil etmektedir.

Çalışmanın örneklemi 205 (E: 26,3\%, K: 73,7\%) üniversite öğrencisinden oluşmaktadır. Örneklemin yaş ortalaması 21.56'dır. Çalışmada organ bağışı tutum ölçeği, dini ibadet ölçeği ve bireysel dindarlık ölçeği kullanılmıştır. Organ Bağışı Tutum Ölçeği, Parisi ve Katz (1986) tarafından geliştirilmiş, Kent ve Owens (1995) tarafından tekrar revize edilmiştir. Sayın (2016) ise organ bağışı tutum ölçeğini Türkçe'ye uyarlamıştır. Dini İbadet ölçeği Ayten (2012) tarafından geliştirilmiştir. Bireysel Dindarlık Ölçeği ise Zagumny vd. (2012) tarafından geliştirilmiş, Ayten (2012) tarafından Türkçe'ye uyarlanmıştır. Çalışmada kullanılan ölçeklerin tümü istatistiki olarak güvenilir ve geçerlilik testlerinden geçmiştir.

Çalışmanın sonuçlarına bakıldığında; cinsiyet farklılaşmasına göre organ bağışı tutum ölçeğinin olumsuz alt boyutu olan bedensel yaralanma korkusu boyutunda istatistiki olarak anlamlı düzeyde farklılaşma bulunmuştur. Ayrıca cinsiyete göre dini ibadet konusunda da gruplar arasında farklılaşma tespit edilmiştir. Bireysel dindarlık ile yardımseverlik ve ahlak/inanç değerleri arasında korelasyon ilişkisi bulgulanmıştır. Dahası organ bağışı tutum ölçeğinin kendi alt boyutları arasında da anlamlı düzeyde korelasyon ilişkisi saptanmıştır. Bireysel dindarlık ile organ bağışının olumlu alt boyutu olan 
yardımseverlik ve ahlak/inanç değerleri boyutu arasında regresyon ilişkisi olduğu ortaya koyulmuştur. Organ bağışı tutumu ölçeğinin ahlaki, dini ve prososyal boyutunu oluşturulan yardımseverlik ve ahlak/inanç değerleri boyutu ile organ bağışı tutumu ölçeğinin olumsuz alt boyutları olan tıbbi ihmal korkusu boyutu ve bedensel yaralanma korkusu boyutu arasında ise negatif yönde regresyon ilişkisi olduğu tespit edilmiştir.

Anahtar Kelimeler: Din Psikolojisi, Organ Bağışı Tutumları, Dindarlık, Dini İbadetler, Bireysel Dindarlık.

\section{Giriş}

Dünyada organ bağışı, milyon başına düşen kadavra donör sayısı (pmp) beklenilenin altında seyretmektedir. ${ }^{1}$ Dünyada milyon başına düşen kadavra donör sayısı en fazla olan ülke İspanya'dır. 2019 yılında, İspanya'da milyon başına düşen kadavra donör sayısı 48.9 olarak tespit edilmiştir. Türkiye' de ise 2019 yılında milyon başına düşen kadavra donör sayısı 7.54 olarak belirlenmiştir. ${ }^{2}$ Türkiye' de organ bağışının kayıt altına alındığı 1997 yılından 2019 yılına kadar organ bağışçı sayısı yükseliş gösterse de beklenilen sayının veya oranın altında kalmıştır. ${ }^{3}$ Ülkemizdeki organ bağışçı sayısının düşük olmasının altında birçok neden yatmaktadır. Dini gerekçelerle organ bağışı yapılmaması ve bu konuda yeteri kadar bilinçli ve bilgili olunmaması en başta gelen nedenlerdendir. Örneğin Türkiye'de 582 örneklemle yapılan bir çalışmada katılımcıların \%58.2'si organ bağışlamak istediklerini ifade etmişlerdir, fakat bu kişilerin sadece \%3.3'ünün organ bağış kartı sahibi olduğu tespit edilmiştir. Ayrıca bu çalışmada katılımcıların \%37.8'inin dini gerekçelerle organ bağışı yapmak istemedikleri ortaya çıkmıştır. ${ }^{4} \mathrm{Bu}$ açıdan bakıldığında algılanan dinin, organ bağışı konusunda engel

1 Hesna Gürler - Ayşe Topal Hançer, “Bir Aile Sağlığı Merkezine Başvuran Bireylerin Organ Bağışı Konusundaki Tutumları", Turkiye Klinikleri Journal of Medical Ethics-Law and History 28/1 (2020), 90-98.

2 www.irodat.org, International Registry In Organ Donation and Transplantation (Barcelona, 2020).

3 Irodat, "Donation 102 Countries Reported since 1996”, DTI (2020).

4 Gürler - Topal Hançer, "Bir Aile Sağlığı Merkezine Başvuran Bireylerin Organ Bağışı Konusundaki Tutumları", 90-98. 
498 | S. KORKMAZ / Organ Bağışı Tutumları ve Dindarlık İlişkisi

teşkil ettiği ifade edilebilir. ${ }^{5}$ Ayrıca organ bağışı konusundaki bilgi eksiklikleri de, insanların organ bağışı davranışlarına yönelmesini engellemektedir. ${ }^{6}$

Yapılan çalışmalara bakıldığında organ bağışı tutumlarında dindarlık veya din belirleyici ve büyük bir etken olarak görünmektedir. ${ }^{7}$ Ülkemizdeki dindarlık oranı değerlendirildiğinde ${ }^{8}$ organ bağışı tutumlarına yönelik davranışlar daha da önem kazanmaktadır. Bu nedenle literatürde din ile organ bağışı ilişkisini araştıran çalışmalara ihtiyaç duyulmaktadır. Bu çalışmayla birlikte literatürdeki ihtiyacı bir anlamda karşılamak için dindarlık ile organ bağışı tutumları ele alınmıştır. Dindarlık, dini ibadet $^{9}$ ve bireysel dindarlık ${ }^{10}$ olarak ele alınırken organ bağışı tutumu; yardımseverlik ve ahlak/inanç değerleri, tıbbi ihmal korkusu ve bedensel yaralanma korkusu ${ }^{11}$ alt boyutları esas alınarak araştırılmıştır. Araştırma, dindarlık oranları yüksek olan İlahiyat öğrencilerinde yapılmıştır. İlahiyat öğrencileri üzerine organ bağışı tutumunun ölçülme nedeni, eğitimli dindarların organ bağışına bakışının değerlendirilmesi ve dindarlıkla ilişkilerinin ortaya koyulmasıdır. Bu çalışmada dini ibadetin ve bireysel dindarlığın olumlu ve olumsuz organ bağışı tutumları üzerindeki etkisi ele alınmıştır. Ayrıca cinsiyete göre değişkenler arasında herhangi bir farklılık olup olmadiğı incelenmiştir.

5 Pınar Yalçın Balçık vd., “Üniversite Öğrencilerinin Organ Bağışına ve Nakline Yönelik Tutumları”, SDÜ Să̆llk Bilimleri Dergisi 10/3 (20 Eylül 2019), 314-319.

6 Gürler - Topal Hançer, "Bir Aile Sağlığı Merkezine Başvuran Bireylerin Organ Bağışı Konusundaki Tutumları", 90-98.

7 Abdullah Özbolat, “'Organlarımla Dirilmek İstiyorum.'- Organ Bağışının DiniToplumsal Arkaplanı", Çukurova Üniversitesi İlahiyat Fakültesi Dergisi (ÇüIFD) 17/1 (30 Haziran 2017), 61-87.

8 Diyanet İşleri Başkanlığı, Türkiye'de Dini Hayat Araştırması (Religious Life Survey in Turkey) (Ankara: Tüik, 2014).

9 Ali Ayten, "Kimlik ve Din: İngiltere'deki Türk Gençleri Üzerine Bir Araştırma", Çukurova Üniversitesi İlahiyat Fakültesi Dergisi (ÇÜIFD) 12/2 (01 Haziran 2012), 101119.

10 M. J. Zagumny vd., "Psychometric analysis of the Religious Identity Index", Presentation at the 24th Annual Convention of the Association for Psychological Science, (May 2012), 107.

11 Bridie Kent - R. Glynn Owens, "Conflicting attitudes to corneal and organ donation: a study of nurses' attitudes to organ donation", International Journal of Nursing Studies 32/5 (1995), 484-492. 
İnsanlığın organ bağışına ilgisi milattan öncelere kadar dayanmaktadır. Organ bağışı ile ilgili somut gelişmeler 19. yüzyılın sonu 20. yüzyılın başlarında, hayvanlar üzerindeki çalışmalarla ortaya çıkmıştır. Birinci Dünya Savaşı ve Büyük Buhran, kısmi olarak organ bağışı çalışmalarını engellemiştir. Bu olaylardan sonra organ bağışı ile ilgili araştırmalar hızlı bir şekilde ilerlemiştir. ${ }^{12}$ Organ bağışına yönelik tıbbi veya bilimsel engeller ortadan kalkmış olsa da insanların bilişsel düzeyde organ bağışı yapmaya ikna olması konusunda birtakım engeller olduğu ifade edilmektedir. Bu engeller dini nedenlerden kaynaklanabildiği gibi organ bağışına ilgi duymamaktan da kaynaklanabilmektedir. ${ }^{13}$ Örneğin 3907 tıp öğrencisi üzerinde bir çalışma yapılmıştır. Bu çalışmaya katılan öğrencilerin \%42'si ateist veya agnostik olduğunu ifade ederken \%58'i kendini dindar olarak belirtmiştir. Çalışmada ateist veya agnostik olanların, organ bağışı fikrine dindar olanlardan daha yatkın olduğu tespit edilmiştir. ${ }^{14}$ İngiltere'de organ bağışı tutumunu artırmak amacıyla dini liderler ve dini gruplarla çalışma yapılmıştır. Bu çalışmada dindarların organ bağışı fikrine ikna ve entegre olmaları ve organ bağışına yönelik olumlu davranışlarının artırılması hedeflenmiştir. ${ }^{15}$ Buradan hareketle din ile organ bağışı tutumları arasında negatif bazı durumların olduğunu ifade etmek mümkündür. Bu araştırmada dindarlık puanları yüksek olan bir örneklemin (İlahiyat öğrencileri) organ bağışına yönelik tutumlarının belirlenmesi ve araştırılmasının oldukça önemli olduğunu belirtmek gerekmektedir.

Bu çalışmada organ bağışı ve dindarlık ilişkisi farklı şekillerde ele alınmıştır. İlk olarak kendini dindar olarak ifade eden kişilerin kadın ve erkek olarak ayrışıp ayrışmadığı incelenmiştir. Ardından çalışmanın temel değişkenleri arasındaki ilişkiye yönelik analizler yapılmıştır. Son

12 Peter K Linden, "History of Solid Organ Transplantation and Organ Donation", Critical Care Clinics 25/1 (2009), 165-184.

13 Yalçın Balçık vd., "Üniversite Öğrencilerinin Organ Bağışına ve Nakline Yönelik Tutumları", 314-319.

14 A. Ríos vd., "Do Religious Factors Influence the Attitude Toward Organ Donation Among Medical Students? A Spanish Multicenter Study", Transplantation Proceedings 51/2 (01 Mart 2019), 250-252.

15 G. Randhawa - J. Neuberger, "Role of Religion in Organ Donation - Development of the United Kingdom Faith and Organ Donation Action Plan", Transplantation Proceedings 48/3 (01 Nisan 2016), 689-694. 
500 | S. KORKMAZ / Organ Bağışı Tutumları ve Dindarlık İlişkisi

olarak dini ibadet ve bireysel dindarlığın; yardımseverlik ve ahlak/inanç değerlerini, tıbbi ihmal korkusunu ve bedensel yaralanma korkusunu yordamasına yönelik testler yapılmıştır. Ayrıca organ bağış tutumu ölçeğinin ${ }^{16}$ dindarlıkla da ilişkili olan yardımseverlik ve ahlak/inanç değerleri boyutunun tibbi ihmal korkusu ve bedensel yaralanma korkusunu ${ }^{17-18}$ istatistiki olarak yordayıp yordamadığı ele alınmıştır. Bu problemler ve teorik zemin üzerine aşağıdaki hipotezler test edilmiştir.

\section{Çalışmanın Hipotezleri}

1- Cinsiyete göre organ bağışı tutumlarında farklılaşma vardır.

2- Cinsiyete göre dini ibadet ve bireysel dindarlıkta farklılaşma vardir.

3- Yardımseverlik ve ahlak/inanç değerleri boyutu ile dini ibadet ve bireysel dindarlık arasında pozitif yönde korelasyon ilişkisi bulunmaktadir.

4- Yardımseverlik ve ahlak/inanç değerleri boyutuyla tıbbi ihmal korkusu ve bedensel yaralanma korkusu arasında negatif yönde ilişki vardir.

5- Dini ibadet, yardımseverlik ve ahlak/inanç değerlerini, tıbbi ihmal korkusunu ve bedensel yaralanma korkusunu yordamaktadir.

6- Bireysel dindarlık, yardımseverlik ve ahlak/inanç değerlerini, tıbbi ihmal korkusunu ve bedensel yaralanma korkusunu yordamaktadir.

7- Yardımseverlik ve ahlak/inanç değerleri boyutu, tıbbi ihmal korkusu ve bedensel yaralanma korkusunu yordamaktadır.

\section{Metot}

$\mathrm{Bu}$ başlık altında çalışmanın örneklem yapısından, verilerin nasıl toplandı̆̆ından, ölçeklerin genel özelliklerinden ve veri analizlerinin nasıl yapıldı̆̆ından bahsedilmiştir.

\section{Örneklem ve Veri Toplama}

Çalışmanın örneklemi, KSÜ İlahiyat Fakültesinde eğitim alan 205 üniversite öğrencisinden oluşmaktadır. Katılımcıların yaş ortalamasının

16 Yazile Yazici Sayin, "Turkish validity and reliability of Organ Donation Attitude Scale", Journal of Clinical Nursing 25/5-6 (01 Mart 2016), 642-655.

17 N. Parisi - I. Katz, "Attitudes toward posthumous organ donation and commitment to donate.", Health psychology: official journal of the Division of Health Psychology, American Psychological Association 5/6 (1986), 565-580.

18 Kent - Owens, "Conflicting attitudes to corneal and organ donation: a study of nurses' attitudes to organ donation", 484-492. 
$21.56(\mathrm{SD}=3.96, R=17-50)$ olduğu tespit edilmiştir. Örneklemin \%26.3'ü erkek (N=54), \%73.7'si ( $=151)$ kadındır. Veriler 4 Haziran 2020 ile 10 Haziran 2020 tarihleri arasında toplanmıştır. Katılımcılar onam formunu onaylayarak ve gönüllülük esasına göre anketi doldurmuşlardır.

\section{Ölçekler}

Kişisel Bilgi Formu: Bu form, katılımcıların yaş ve cinsiyet gibi demografik özelliklerinin belirlenmesi ve hipotezlerin test edilmesi amacıyla araştırmacı tarafından hazırlanmıştır.

Organ Bağışı Tutum Ölçeği: Organ bağışı tutum ölçeği Parisi ve Katz (1986) ${ }^{19}$ tarafından geliştirilmiş, Kent ve Owens (1995) 20 tarafından düzenlenmiştir. Sayın (2016), ${ }^{21}$ organ bağ1ş ölçeğini Türkçe'ye uyarlamıştır. Ölçek, 23 pozitif, 23 negatif madde olmak üzere 46 maddeden oluşmaktadır. Türkçe uyarlamasında istatistiksel uyum gerekçesiyle madde sayısı 40'a düşmüştür. ${ }^{22}$ Ölçek 6 'lı likert tipinde düzenlenmiştir (1= Hiç katılmıyorum, $6=$ Tamamen katıllıorum). Organ bağışı tutum ölçeğinin pozitif ve negatif olmak üzere iki yönü bulunmaktadır. Organ bağışı tutum ölçeği; yardımseverlik ve ahlaki değer/inanç boyutu, tıbbi ihmal korkusu boyutu ve bedensel yaralanma korkusu boyutu olarak üç boyutta sınıflandırılmıştır. Organ bağışı tutum ölçeğinin pozitif yönünü yardımseverlik ve ahlak/inanç değerleri boyutu oluşturmaktadır. Organ bağışı tutum ölçeğinin negatif yönünü ise tıbbi ihmal korkusu boyutu ve bedensel yaralanma korkusu boyutu oluşturmaktadır. Organ bağışı tutum ölçeğinin alt boyutu olan yardımseverlik ve ahlak/inanç değerleri boyutunun Cronbach's Alpha değeri $(\alpha) .899$ 'dur. Tibbi ihmal korkusu alt boyutunun Cronbach's Alpha değeri $(\alpha)$.715'dir. Bedensel yaralanma korkusu boyutunun Cronbach's Alpha değeri $(\alpha)$ ise .714 olarak tespit edilmiştir.

Dini İbadet Ölçeği: Dini ibadet ölçeği, Ayten (2012) ${ }^{23}$ tarafından geliştirilmiştir. Ölçek 6 maddeden oluşmakta ve 5'li likert tipindedir (1=

19 Parisi - Katz, "Attitudes toward posthumous organ donation and commitment to donate", 565-580.

20 Kent - Owens, "Conflicting attitudes to corneal and organ donation: a study of nurses' attitudes to organ donation", 484-492.

21 Yazici Sayin, "Turkish validity and reliability of Organ Donation Attitude Scale", 642-655.

22 Yazici Sayin, "Turkish validity and reliability of Organ Donation Attitude Scale", 642-655.

23 Ayten, “Kimlik ve Din: İngiltere' deki Türk Gençleri Üzerine Bir Araştırma”, 101-119. 
502 | S. KORKMAZ / Organ Bağışı Tutumları ve Dindarlık İlişkisi

Hiç, 5= Her zaman). Dini ibadet ölçeğinde Cuma namazına gitme ve bayram namazlarına gitme maddeleri de bulunmaktadır. Cinsiyet açısından düşünüldüğünde kadınlar Cuma ve Bayram namazına genel itibariyle gitmemektedir. Dini ibadet ölçeğinde kadınların ortalama puanlarına olumsuz etki etmesi sebebiyle Cuma namazına ve bayram namazlarına gitme maddeleri ölçekten çıkartılmıştır. Dini ibadet ölçeği Müslümanların temel dini ibadetlerini belirlemektedir. Ölçeğin maddeleri, namaz kılma, oruç tutma, Kur'an okuma (Türkçe ya da Arapça) ve dua etmeden oluşmaktadır. Dini ibadet ölçeğinin Cronbach's Alpha değeri $(\alpha) .660^{\prime}$ dir.

Bireysel Dindarlık Ölçeği: Bireysel dindarlık ölçeği Zagumny vd. (2012) ${ }^{24}$ tarafından geliştirilmiştir. Ölçek 6 maddeden oluşmakta olup 5'li likert tipindedir. Bireysel dindarlık ölçeği Ayten (2013) tarafından Türkçe'ye uyarlanmıştır. Farklı çalışmalarda ${ }^{25}$ kullanılan ölçeğin psikometrik değerlerinin yeterince uygun olduğu tespit edilmiştir. ${ }^{26}$ Bireysel dindarlık ölçeğinin Cronbach's Alpha değeri $(\alpha)$.867' dir.

\section{Veri Analizi}

Verilerin analizi SPSS ve AMOS programlarıyla yapılmıştır. İlk olarak ölçeklerin güvenirlik ve geçerlilik değerlerine bakılmıştır. Ardından demografik değişkenlere yönelik betimsel istatistikler tespit edilmiştir. Cinsiyete göre değişkenlerde farklılaşma olup olmadiğı incelenmiştir. Ardından değişkenlere ilişkin korelasyon ilişkileri ele alınmıştır. Son olarak yapısal eşitlik modeline dayalı olarak regresyon ilişkileri analiz edilmiştir. Özet olarak bu çalışmada betimsel analiz, güvenirlik analizi, t-test fark analizi, korelasyon analizi ve regresyon analizi yapılmıştır.

\section{Bulgu ve Tartışma}

$\mathrm{Bu}$ bölümde t-test, korelasyon ve regresyon ilişkileri ele alınmıştır. Cinsiyete göre organ bağışına bağlı olarak bedensel yaralanma korkusu ve dini ibadetteki farklılaşmalar Tablo 1'de aktarılmıştır. Çalışmanın temel değişkenleri arasındaki korelasyon ilişkisi Tablo 2' de ve regresyon

24 Zagumny vd., "Psychometric analysis of the Religious Identity Index", 107.

25 Ali Ayten - Sezai Korkmaz, "The relationships between religiosity, prosociality, satisfaction with life and generalised anxiety: a study on Turkish Muslims", Mental Health, Religion and Culture 22/10 (26 Kasım 2019), 980-993.

26 Ali Ayten, “Din ve Sağlık: Bireysel Dindarlık, Sağlık Davranışları ve Hayat Memnuniyeti İlişkisi Üzerine Bir Araştırma", Dinbilimleri Akademik Araştırma Dergisi 13/1 (01 Şubat 2013), 7-31. 
ilişkilerine yönelik bulgular Tablo 3'te sunulmuştur. Bulguların yanı sıra literatür eşliğinde yorumlama ve tartışmaya da yer verilmiştir.

\section{Cinsiyete Göre Farklılaşma}

Tablo 1'de cinsiyete göre bedensel yaralanma ve dini ibadet konusunda farklılaşma incelenmiştir. Tablo 1'de cinsiyete göre katılımcı sayıları, ortama puanları, standart sapmaları, serbestlik dereceleri, $\mathrm{t}$ değerleri ve anlamlılık düzeyleri verilmiştir. Cinsiyete göre diğer değişkenlerde istatistiki olarak anlamlı düzeyde farklılaşma olmadığından Tablo 1'de yer verilmemiştir.

Tablo 1: Cinsiyete Göre Bedensel Yaralanma Korkusu (BYK) ve Dini İbadet

\begin{tabular}{lccccccc}
\hline & Cinsiyet & $\mathrm{N}$ & $\mathrm{M}$ & $\mathrm{Std} . \mathrm{S}$. & $\mathrm{df}$ & $\mathrm{t}$ & $\mathrm{p}$ \\
\hline BYK & Erkek & 54 & 2.93 & 1.41 & 203 & 2.230 & .027 \\
& Kadın & 151 & 2.53 & 1.04 & & & \\
\hline Dini İbadet & Erkek & 54 & 4.25 & .72 & 203 & -2.604 & .010 \\
& Kadın & 151 & 4.47 & .41 & & & \\
\hline
\end{tabular}

Tablo 1'e bakıldığında cinsiyete göre bedensel yaralanma korkusu $\left(\mathrm{t}_{(203)}=2.230 ; \mathrm{p}<0,05\right) \quad$ ve dini ibadet $\left(\mathrm{t}_{(203)}=-2.604 ; \mathrm{p}<0,05\right)$ konularında istatistiki olarak anlamlı farklılaşma olduğu görülmüsştür. Cinsiyete göre organ bağışı tutumlarında erkekler $(\mathrm{M}=2.93)$ kadınlardan $(\mathrm{M}=2.53)$ daha fazla bedensel yaralanma korkusu yaşamaktadır. Çalışmanın "cinsiyete göre organ bă̆̆ışı tutumlarında farklılaşma vardır" hipotezi sadece bedensel yaralanma korkusu (BYK) boyutunda desteklenmiştir. Fark testlerine göre kurulan "cinsiyete göre dini ibadet ve bireysel dindarlikta farklılaşma vardır" hipotezi ise sadece dini ibadet boyutunda doğrulanmıştır. Buna göre cinsiyete göre bireysel dindarlıkta, organ bağışı tutumlarından yardımseverlik ve ahlak/inanç değerleri boyutunda ve tıbbi ihmal korkusu boyutunda istatistiki olarak anlamlı düzeyde farklılaşma olmadığ 1 tespit edilmiştir.

Tablo 1'deki bulgulara göre organ bağışı tutumu ölçeğinin alt boyutu olan bedensel yaralanma korkusu boyutu, organ bağışına yönelik olumsuz yönü teşkil etmektedir. Bir anlamda bedensel yaralanma korkusu, insanları organ bağışına yönelmekten alıkoymaktadır. Yukarıdaki (bk. Tablo 1) tablodaki veriler erkeklerin, kadınlardan daha fazla bedensel yaralanma korkusu yaşadıklarını göstermektedir. Aynı zamanda erkekler, organ bağışı tutumlarına kadınlardan daha olumsuz yaklaşmaktadır demek de mümkündür. Avustralya'da 509 kişi üzerine yapılan bir çalışmada da bu bulgulara 
504 | S. KORKMAZ / Organ Bağışı Tutumları ve Dindarlık İlişkisi

benzer bir durum ortaya çıkmıştır. ${ }^{27}$ Çalışmanın verilerine göre kadınlar, erkeklerden ve yaşlı insanlardan daha fazla organ bağışı tutumlarına yönelmektedir. Ayrıca çalışmada kadınların, erkek ve yaşlı insanlara göre organ bağışı konusunda daha fazla bilgi sahibi olduğu ve kadınların, organ bağışı tutumlarında daha istekli oldukları tespit edilmiştir. ${ }^{28}$

Türkiye'de 582 kişi üzerinde yapılan bir organ bağışı tutumu araştırmasında da benzer durumun olduğu ortaya çıkmıştır. Cinsiyete göre organ bağışı tutumuna olumsuz yaklaşım sergilemede erkeklerin puan ortalamaları, kadınlardan daha yüksek çıkmıştır. Bu çalışmada da cinsiyete göre erkekler, kadınlardan daha az organ bağışı tutumu sergileme yönelimi göstermiştir. ${ }^{29} 230$ üniversite öğrencisi üzerinde yapılmış başka bir çalışmada organ bağışı tutumları konusunda cinsiyete göre kadınlar lehine bir durum söz konusudur. Kadınlar erkeklere göre organ bağışında daha fazla gönüllü davranmışlardır..$^{30}$ Cinsiyete bağlı bulgulara göre oluşmuş olan literatür değerlendirildiğinde genel itibariyle kadınlar, erkeklerden daha fazla organ bağış̧̧ısı olmak istemektedir. Bu çalışmada da literatürü destekleyen bir sonuç ortaya çıkmıştır.

Cinsiyete göre dini ibadete bakıldığında literatürde çeşitli bulgulara sahip çalışmalar bulunmaktadır. Örneğin Yapıcı'nın (2012) yapmış olduğu meta-analiz denemesi çalışmasında dini ibadet konusunda kadınların daha yüksek ortalamaya sahip olduğu saptanmıştır. ${ }^{31}$ Uysal'ın (2016) yapmış olduğu çalışmada da kadınların dindarlık oranlarının erkeklerden daha yüksek olduğu tespit

27 Claire E. Wakefield vd., "Religious and ethnic influences on willingness to donate organs and donor behavior: An Australian perspective", Progress in Transplantation 21/2 (01 Haziran 2011), 161-168.

28 Wakefield vd., "Religious and ethnic influences on willingness to donate organs and donor behavior: An Australian perspective", 161-168.

29 Gürler - Topal Hançer, “Bir Aile Sağlığı Merkezine Başvuran Bireylerin Organ Bağışı Konusundaki Tutumları", 90-98.

30 Richard M. Ryckman vd., "Intrinsic-Extrinsic Religiosity and University Students' Willingness to Donate Organs Posthumously", Journal of Applied Social Psychology 34/1 (01 Ocak 2004), 196-205.

31 Asım Yapıc1, "Türk Toplumunda Cinsiyete Göre Dindarlık Farklılaşması: Bir MetaAnaliz Denemesi", Fırat Üniversitesi İlahiyat Fakültesi Dergisi 17/2 (2012), 1-34. 
edilmiştir. ${ }^{32}$ Yapılan başka bir çalışmada istatistiki olarak anlamlı olmasa dahi kadınların dindarlık ortalamaları, erkeklerden yüksek çıkmıştır. ${ }^{33}$ Bunun aksine erkeklerin, kadinlardan daha dindar veya dindarlık puanlarının yüksek olduğunu bulgulayan çalışmalar da bulunmaktadır. ${ }^{34-35}$ Fakat literatürdeki genel kabul, kadınların dindarlık veya dini ibadet ortalama puanları erkeklerden daha yüksek olduğu yönündedir. Literatürün geneli ele alındığında ve ayrıca Yapıcı'nın meta-analizi ${ }^{36}$ değerlendirildiğinde Türkiye'de dini ibadet konusunda cinsiyete göre kadınların, erkeklerden daha fazla dini ibadete yöneldiğini ifade etmek mümkündür. Bu veriler çalışmanın bulgularını da destekler niteliktedir.

İtalya'da tıp öğrencileri üzerine yapılan bir çalışmada dindarlık, cinsiyet, hobi ve ikamet yeri gibi birçok demografik özelliklerle organ bağışı ve organ nakli arasındaki ilişkiler incelenmiştir. Organ nakli konusunda cinsiyete göre kadınlar ile erkekler arasındaki istatistiki olarak herhangi bir farklılaşma olmadığı tespit edilmiştir. Cinsiyete göre organ bağışı konusuna bakıldığında kadınların ortalama puanları erkeklerin ortalama puanlarından anlamlı düzeyde farklılaşmıştır. Bu bağlamda organ bağışı konusunda kadınların, erkeklerden daha istekli olduğu tespit edilmiştir. ${ }^{37} \mathrm{Bu}$ bulgular, Tablo 1'deki kadınların erkeklere oranla bedensel yaralanmadan daha az korkmaları ve organ bağışına yönelik kadınların daha olumlu yaklaşım sergilemeleri ilişkisini

32 Veysel Uysal, "Gençlerde Empati, Anne-Baba Tutumları ve Dindarlık", Dokuz Eylül Ünivesitesi İlahiyat Fakültesi Dergisi Din Psikolojisi Özel Sayısı (15 Nisan 2016), 7-40.

33 Hüsnü Bodur - Sezai Korkmaz, "İlahiyat Öğrencilerinde Sosyal Medya Kullanımı ve Dindarlık İlişkisi", Kahramanmaraş Sütçü İmam Üniversitesi İlahiyat Fakültesi Dergisi 30 (2017), 329-351.

34 Sezai Korkmaz, "Dindarlık ile Ego Sağlamlı̆̆ı ve Empati Arasındaki İlişkilerin İncelenmesi", Bilimname 2018/2 (31 Ekim 2018), 587-607.

35 Sezai Korkmaz - Ali Ulvi Mehmedoğlu, "Dindarlık, Siber Zorbalık ve Problemli İnternet Kullanımı İlişkisine Dair Nicel Bir Araştırma", Dini Araştırmalar 21/53 (15 Haziran 2018), 35-54.

36 Yapıcı, "Türk Toplumunda Cinsiyete Göre Dindarlık Farklılaşması: Bir Meta-Analiz Denemesi", 1-34.

37 P. Burra vd., "Changing attitude to organ donation and transplantation in university students during the years of Medical School in Italy", Transplantation Proceedings 37/2 (1 March 2005), 547-550. 
506 | S. KORKMAZ / Organ Bağışı Tutumları ve Dindarlık İlişkisi

desteklemektedir. Burra ve diğerlerinin ${ }^{38}$ yapmış olduğu çalışmada kadınların tutumları, organ bağışı konusunda erkeklerden daha olumluyken, Tablo 1'deki bulgulara göre, kadınların bedensel yaralanma korkusunun erkeklerden daha düşük olması, kadınların organ bağışı tutumlarının kısmi olumlu bir yönelimi olarak düşünülebilir. Çünkü kadınların organ bağışı tutumlarının tam anlamda olumlu olabilmesi için organ bağışı tutumunun diğer olumsuz boyutu olan tıbbi ihmal korkusu boyutunda da farklılaşması olması gerekmektedir. Bu nedenle kısmi olumlu bir yönelim söz konusudur demek en doğru değerlendirmedir diyebiliriz.

\section{Değişkenlerin Korelasyon İlişkileri}

Korelasyon matrisi Tablo 2'de aktarılmıştır. Araştırmanın hipotezlerine dayalı olarak değişkenler arasındaki ilişkiler incelenmiştir. $\mathrm{Bu}$ başlık altında organ bağışı tutum ölçeğinin alt boyutları olan yardımseverlik ve ahlak/inanç değerleri (YAID) boyutu, tıbbi ihmal korkusu (TIK) boyutu, bedensel yaralanma korkusu (BYK) boyutu, dini ibadet ve bireysel dindarlık arasındaki korelasyon ilişkilerinin yönleri ve anlamlılık düzeyleri Tablo 2'de aktarıldığ 1 gibidir.

Tablo 2: Korelasyon Matrisi

\begin{tabular}{llllll}
\hline & 1 & 2 & 3 & 4 & 5 \\
\hline 1.Yaid & 1 & & & & \\
2.Tik & $-.186^{* *}$ & 1 & & & \\
3.Byk & $-.370^{* *}$ & $.557^{* *}$ & 1 & & \\
4.Dini İbadet & .128 & .016 & -.003 & 1 & \\
5.Bireysel Dindarlık & $.187^{* *}$ & .093 & .051 & $.688^{* *}$ & 1 \\
\hline${ }^{* *} \mathrm{p}<0.01$ & & & & &
\end{tabular}

Tablo 2'ye bakıldığında dini ibadetle yardımseverlik ve ahlak/inanç değerleri (YAID) arasında $\left(\mathrm{r}_{(205)}=.128 ; \mathrm{p}>0.01\right)$; dini ibadetle tıbbi ihmal korkusu (TIK) arasinda $\left(\mathrm{r}_{(205)}=.016 ; \mathrm{p}>0.01\right)$ ve dini ibadetle bedensel yaralanma korkusu (BYK) arasinda $\left(\mathrm{r}_{(205)=-.003 ;} \mathrm{p}>0.01\right)$ istatistiki olarak anlamlı derecede korelasyon ilişkisi olmadığ bulgulanmıştır. Bireysel dindarlıkla organ bağışı tutumlarından yardımseverlik ve ahlak/inanç değerleri arasında $\left(\mathrm{r}_{(205)}=.187 ; \mathrm{p}<0.01\right)$ pozitif yönde ilişki olduğu görülmüştür. Bireysel dindarlık ile tıbbi ihmal korkusu $\left(\mathrm{r}_{(205)=.093 ;} \mathrm{p}>0.01\right)$ ve bedensel yaralanma korkusu

38 Burra vd., "Changing attitude to organ donation and transplantation in university students during the years of Medical School in Italy", 547-550. 
$\left(\mathrm{r}_{(205)}=.051 ; \mathrm{p}>0.01\right)$ arasında istatistiki olarak anlamlı düzeyde ilişki olmadığ 1 tespit edilmiştir. Bu bulgulara göre çalışmanın "yardımseverlik ve ahlak/inanç değerleri boyutu ile dini ibadet ve bireysel dindarlı arasinda pozitif yönde korelasyon ilişkisi bulunmaktadır" hipotezi sadece bireysel dindarlık ile yardımseverlik ve ahlak/inanç değerleri boyutunda desteklenmiştir.

Organ bağış tutumu ölçeğinin kendi alt boyutları arasındaki korelasyon ilişkisine bakıldığında; yardımseverlik ve ahlak/inanç değerleri boyutuyla tıbbi ihmal korkusu arasında $\left(\mathrm{r}_{(205)=-.186 ;} \mathrm{p}<0.01\right)$ ve yardımseverlik ve ahlak/inanç değerleri boyutu ile bedensel yaralanma korkusu $\left(\mathrm{r}_{(205)}=.370 ; \mathrm{p}<0.01\right)$ arasında negatif yönde anlamlı düzeyde korelasyon ilişkisi olduğu saptanmıştır. Organ bağışı tutumu bulgularına göre çalışmanın "yardımseverlik ve ahlak/inanç değerleri boyutuyla tibbi ihmal korkusu ve bedensel yaralanma korkusu arasinda negatif yönde ilişski vardır" hipotezi doğrulanmıştır.

Amerika'da 190 üniversite öğrencisi üzerinde yapılan bir çalışmada bilgi sahibi olma ve dindarlığın, organ bağışı tutumuna etkisi araştırılmıştır. Bu çalışmada öğrencilerin organ bağışı, dindarlığı, eğitim düzeyi, yaşarken organ bağışı yapan kişiyi tanıma, öldükten sonra organ bağışı yapan birine şahit olma ve organ bağışı nakli yapılmış bir kişiyi tanıma ve ayda dini etkinliklere katılma sıklıkları temel değişken olarak incelenmiştir. Dindarlık ile organ bağışı arasında anlamlı düzeyde korelasyon ilişkisi olmadığı, organ bağışının, organ nakli yapılmış birini tanıma ve eğitimle direk ilişkisinin olduğu tespit edilmiştir. ${ }^{39}$ Buradan hareketle organ nakli olmuş birinin bilinmesi ve organ bağışına yönelik bilinç kazanmanın oldukça önemli olduğu görülmektedir. Ayrıca dini etkinliklere katılma sıklığı ile yaşarken organ bağışçısı olan birini tanıma arasında ve dini etkinliklere katılma sıklı̆̆ ile organ nakli olmuş birini tanıma arasında pozitif yönde korelasyon olduğu ortaya çıkmıştır. ${ }^{40}$ Buradan hareketle organ bağışı tutumlarında sosyalleşmenin, dini etkinliklere katılımın ve organ bağışı yapmış veya olmuş birini tanımanın oldukça önemli olduğu görülmüştür.

39 Ferid Krupic vd., "The Influence of Age, Gender and Religion on Willingness to be an Organ Donor: Experience of Religious Muslims Living in Sweden", Journal of Religion and Health 58/3 (2019), 847-859.

40 Krupic vd., "The Influence of Age, Gender and Religion on Willingness to be an Organ Donor: Experience of Religious Muslims Living in Sweden", 847-859. 
508 | S. KORKMAZ / Organ Bağıısı Tutumları ve Dindarlık İlişkisi

Türkiye'de dindar insanlar üzerinde yapılan bir çalışmada katılımcıların \%86'sı İslâm inançları açısından organ bağışı ve nakli yapmanın insana yakışan bir davranış olduğunu ve organ bağışı yapabileceğini ifade etmiştir. Örneklemin \%10’u organ bağışı yapmak istemediğini belirtmiştir. Organ bağışı yapmayacağını ifade edenlerin \%17'si organ bağışının İslami inanca uymadığına inanmaktadır. Organ bağışı yapmayacağını söyleyen diğer \%17'lik kesim ise öldükten sonra beden bütünlüğünün korunması gerektiğini savunmuştur. Organ bağışlamayacağını ifade edenlerin \%28'i korkudan, \%10'u ise ölmeden önce tıbbi ihmal korkusundan yanaşmadığını söylemiştir. ${ }^{41}$ Buradan hareketle, katılımcıların yüksek çoğunluğunun organ bağışına yönelik olumlu tutumlarının olması, dindar insanların inanç anlamında uyum sağladıklarını göstermektedir. Bireysel dindarlık ve değerler anlamında yaklaşım gösteren dindar bireyler, organ bağışına daha olumlu bakabilmektedir. Buradaki veriler Tablo 2'deki bireysel dindarlık ile yardımseverlik ve ahlak/inanç değerleri arasındaki pozitif ilişkiyi destekler niteliktedir.

İsveç'te 18 erkek ve 18 kadın olmak üzere 36 kişi üzerinde yapılan nitel bir çalışmada din ve bilinç artışının organ bağışı üzerindeki etkileri araştırılmıştır. Elde edilen bulgulara göre kişilerin dindarlıkları ile organ bağışı tutumları arasında ilişkiler olduğu görülmüştür. Bireylerin dini bilgileri ile organ bağışına yönelik bilinçleri artırıldığında, organ bağışı konusundaki tutumların değiştiği saptanmıştır. ${ }^{42}$ İsveç'teki çalışmanın din ile organ bağışı tutumu arasındaki ilişkide bu çalışmanın bulgularıyla paralellik göstermektedir. Belki de nitel çalışmada olduğu gibi inanç ile organ bağışını bütünleştirici çalışmaların daha yararlı sonuçlar ortaya koyacağı da düşünülebilir.

Türkiye'de 724 üniversite öğrencisi üzerinde bir çalışma gerçekleştirilmiştir. Yapılan çalışmada dindarlık, vücut bütünlüğü, kitlesel medya araçları ve bilgi sahibi olmanın organ bağışı üzerinde etkisi tespit edilmeye çalışılmıştır. Bu çalışmada dindarlık, vücut bütünlüğü, medya etkisi ve bilgi sahibi olma arasında ilişkiler olduğu saptanmıştır. Korelasyon ilişkilerin vücut bütünlüğünün dindarlık ve

${ }^{41}$ N. Keçecioğlu vd., “Attitudes of religious people in Turkey regarding organ donation and transplantation", Transplantation Proceedings 32/3 (May1s 2000), 629-630.

42 Ferid Krupic, "The Impact of Religion and Provision of Information on Increasing Knowledge and Changing Attitudes to Organ Donation: An Intervention Study", Journal of Religion and Health 58/3 (14 Aralık 2019), 1-14. 
medya ile pozitif yönde ilişkili, bilgi sahibi olma ile negatif yönde ilişkili olması kayda değerdir. ${ }^{43} \mathrm{Bu}$ çalışmanın bulgularına göre dindarlık puanları yüksek olanların beden bütünlügünün bozulmasını isteme oranlarının da düşük olduğu tespit edilmiştir. Aslında beden bütünlüğü ile dindarlık arasında pozitif yönde ilişkinin olması, organ bağışına yönelik tutumun olumsuz olduğu anlamına da gelmektedir. Çünkü beden bütünlügünün bozulmasını istemeyenler genel itibariyle dini inançlara ve öldükten sonraki hayata yönelik düşüncelerinden dolayı bu durumu savunmaktadır. Ayrıca beden bütünlügü ile bilgi sahibi olma durumu arasında negatif yönde ilişkinin olması, bilincin veya bilginin; beden bütünlüğüne dair inançları değiştirdiğini göstermektedir. Bu açıdan değerlendirme yapıldığında bireysel dindarlık, kişinin kurumsal dinden öte daha özel dünyasını kapsamaktadır. Bireysel dindarlık ${ }^{44}$ aynı zamanda sorgulanması ve bireyin kendi kendine anlam oluşturmasını da içine aldığından organ bağışına yönelik tutumları değiştirme etkisinin ${ }^{45}$ daha yüksek olduğunu ifade edebiliriz.

\section{Değişkenlerin Regresyon İlişkileri}

$\mathrm{Bu}$ başlık altında değişken arasındaki regresyon ilişkileri ele alınmıştır. Dini ibadet ve bireysel dindarlığın yardımseverlik ve ahlak/inanç değerlerini (YAİB), tıbbi ihmal korkusunu (TIK) ve bedensel yaralanma korkusunu (BYK) yordaması incelenmiştir. Ayrıca yardımseverlik ve ahlak/inanç değerlerinin tıbbi ihmal korkusunu ve bedensel yaralanma korkusunu yordaması araştırılmıştır. Tablo 3'te hipotezlere bağlı olarak dini ibadet ve bireysel dindarlığın yardımseverlik ve ahlak/inanç değerlerini yordaması, tıbbi ihmal korkusunu ve bedensel yaralanma korkusunu yordaması aktarılmıştır. Son olarak organ bağışı tutum ölçeğinin alt boyutları arasındaki regresyon ilişkileri Tablo 3'te sunulmuştur.

43 Ibrahim Arisal - Tarik Atalar, "Influence of knowledge, bodily integrity, religion and media on attitudes toward organ donation on the university campus", International Journal of Nonprofit and Voluntary Sector Marketing 25/1 (23 Şubat 2020), 1647.

44 Zagumny vd., "Psychometric analysis of the Religious Identity Index", 107.

45 Krupic, "The Impact of Religion and Provision of Information on Increasing Knowledge and Changing Attitudes to Organ Donation: An Intervention Study", 114. 
510 | S. KORKMAZ / Organ Bağışı Tutumları ve Dindarlık İlişkisi

Tablo 3: Regresyon Ağırlıkları

\begin{tabular}{lcccc}
\hline & Std. C. $(\beta)$ & Std. Er. & $t$ & $p$ \\
\hline Dini ibadet ---> YAİD & .128 & .144 & 1.848 & .065 \\
Dini ibadet ---> TİK & .016 & .162 & .225 & .822 \\
Dini ibadet ---> BYK & -.003 & .158 & -.044 & .965 \\
Bireysel dindarllk ---> YAİD & .187 & .145 & 2.714 & $.007^{*}$ \\
Bireysel dindarlık ---> TİK & .093 & .164 & 1.330 & .183 \\
Bireysel dindarlık ---> BYK & .051 & .160 & .729 & .466 \\
YAİD ---> TIK & -.186 & .077 & -2.709 & $.007^{*}$ \\
YAİD ---> BYK & -.370 & .070 & -5.693 & $* * *$ \\
\hline$* * * p<0.001 ;{ }^{*} \mathrm{p}<0.01$ (two-tailed) & & &
\end{tabular}

Tablo 3'teki regresyon analizi bulgularına bakıldığında dini ibadet ile yardımseverlik ve ahlak/inanç değerleri $(\beta=.128 ; \mathrm{p}>0.001)$, dini ibadet ile tıbbi ihmal korkusu $(\beta=.016 ; \mathrm{p}>0.001)$ ve dini ibadet ile bedensel yaralanma korkusu $(\beta=-.003 ; \mathrm{p}>0.001)$ arasında istatistiki olarak anlamlı düzeyde ilişki olmadığı tespit edilmiştir. Bu verilere göre çalışmanın "dini ibadet, yardımseverlik ve ahlak/inanç değerlerini, tıbbi ihmal korkusunu ve bedensel yaralanma korkusunu yordamaktadır" hipotezi desteklenmemiştir. Bireysel dindarlık ise yardımseverlik ve ahlak/inanç değerlerini $(\beta=.187 ; \mathrm{p}<0.001)$ anlamlı düzeyde yordamıştır. Bireysel dindarlık, yardımseverlik ve ahlak/inanç değerlerinin \%19'unu açıklamıştır. Bireysel dindarlık, tıbbi ihmal korkusu $(\beta=.093 ; \mathrm{p}>0.001)$ ve bedensel yaralanma korkusunu $(\beta=.051 ; \mathrm{p}>0.001)$ ise anlamlı düzeyde yordamamıştır. Bireysel dindarlıkla ilgili oluşturulan "bireysel dindarlık, yardımseverlik ve ahlak/inanç değerlerini, tıbbi ihmal korkusunu ve bedensel yaralanma korkusunu yordamaktadır" hipotezi sadece bireysel dindarlık ile yardımseverlik ve ahlak/inanç değerleri boyutu arasındaki regresyon ilişkisinde doğrulanmıştır.

Organ bağışı tutumunun alt boyutları arasındaki regresyon ilişkisine bakıldığında yardımseverlik ve ahlak/inanç değerleri boyutu, tıbbi ihmal korkusunu $(\beta=-.186 ; \mathrm{p}<0.001)$ ve bedensel yaralanma korkusunu $(\beta=-.370 ; \quad \mathrm{p}<0.001)$ negatif yönde yordamaktadır. Yardımseverlik ve ahlaki/inanç boyutu, tıbbi ihmal korkusunun \%19'unu ve bedensel yaralanma korkusunun \%37'sini açıklamaktadır. Bulgulara göre çalışmanın organ bağışı tutumu alt boyutlarına yönelik kurulan "yardımseverlik ve ahlak/inanç değerleri boyutu, tıbbi ihmal korkusu ve bedensel yaralanma korkusunu yordamaktadı" hipotezi desteklenmiştir. 
Organ bağışının önünde en büyük engellerden biri dini gerekçeler ${ }^{46-47}$ olurken, diğer gerekçeler ise ailenin izin vermemesi ${ }^{48}$ ve organ bağışı konusunda yeterince bilgi sahibi olmama ${ }^{49}$ durumudur. Dindarlığın, organ bağışı tutumlarını olumlu/olumsuz etkilemesi ele alındığında öte dünya inancı, cennet ve cehennem inancı bağlamında öldükten sonra vücut bütünlüğünün bozulmamasına yönelik düşünceler organ bağışı tutumlarını etkilemektedir. Yapılan bir çalışmada ölüm sonrası yaşam, öldükten sonra vücut bütünlügünün korunması ve dini baskıların organ bağışı tutumlarını yordadığ 1 tespit edilmiştir. ${ }^{50} \mathrm{Bu}$ çalışmada Tablo $3^{\prime}$ teki regresyon bulgularına bakıldığında bireysel dindarlığın, organ bağışı tutum ölçeğinin alt boyutu olan yardımseverlik ve ahlak/inanç değerleri boyutunu yordadığ1 görülmektedir. Buradan hareketle kurumsal dinin baskılarından ziyade bireysel dindarlığa yönelen insanların organ bağışına yönelik tutumlarının daha olumlu olacağını ifade etmek mümkündür. Dini ibadetlerin organ bağışı tutumlarıyla ilişkili olmaması da bunu göstermektedir.

Literatürde yapılan başka bir çalışmada ise eğitimin (organ bağışına yönelik bilinçli olma), öldükten sonra organ bağışı yapmış birini tanımış olmak ve organ bağışı yapılmış birini tanımanın organ bağışını yordadığı tespit edilmiştir. Ayrıca dindarlığın organ bağışını yordadığı bulgulanmıştır. Hiyerarşik regresyon analizinde dindarlık, eğitim, öldükten sonra organ bağışı yapmış birini tanımış olmak ve organ bağışı yapılmış birini tanıma değişkenlerinin hepsinin birden, organ bağışı tutumlarının \%24.95'ini açıkladığı ifade edilmiştir. ${ }^{51} \mathrm{Bu}$ bulgulara göre organ bağışına yönelik bilinç kazanmanın, dindarlığın,

46 Emel Güder vd., "Attitudes and Behaviors Regarding Organ Donation: a Study on Officials of Religion in Turkey", Journal of Religion and Health 52/ (2013), 439-449.

${ }_{47}$ Krupic vd., "The Influence of Age, Gender and Religion on Willingness to be an Organ Donor: Experience of Religious Muslims Living in Sweden", 847-859.

48 Fatma Can, "Organ Bağışında Aile Onayı Üzerine Bir Gözden Geçirme”, NesnePsikoloji Dergisi 5/09 (2017), 131-149.

49 Gürler - Topal Hançer, “Bir Aile Sağlığı Merkezine Başvuran Bireylerin Organ Bağışı Konusundaki Tutumları", 90-98.

50 Sıla Demir - Nuray Sakallı-Uğurlu, "Ölüm Belirginliği ve Yardım Hatırlatıcısı ile Organ Bağışını Teşvik Etme”, I. Sosyal Psikoloji Kongresi (Ankara: Başkent Üniversitesi, 2016), 431-446.

51 Krupic vd., "The Influence of Age, Gender and Religion on Willingness to be an Organ Donor: Experience of Religious Muslims Living in Sweden", 847-859. 
512 | S. KORKMAZ / Organ Bağışı Tutumları ve Dindarlık İlişkisi

organ bağışı yapmış ve organ bağışı yapılmış birini tanımanın oldukça önemli olduğunu söylemek gerekmektedir. Çalışmanın Tablo 3'teki bulgularına paralel olarak bireysel dindarlık, organ bağışının dindarlıkla da ilişkili olan alt boyutu yardımseverlik ve ahlak/inanç değerleri boyutunun da önemi ortaya çıkmıştır.

Yapılan bir çalışmada dini inanç, medya etkisi, bilgi sahibi olma ve vücut bütünlüğünün organ bağışını yordayıp yordamadığı test edilmiştir. Hiyerarşik regresyon ilişkisi değil de her bir değişkenin direk etkisi incelenmiştir. Çalışmanın bulgularına göre bedensel bütünlük değişkeni organ bağışını negatif yönde anlamlı düzeyde yordamıştır. Vücut bütünlüğ̈̈, organ bağışının \%27'sini negatif yönde açıklamaktadır. Dindarlık değişkeninin organ bağışı tutumlarını negatif yönde yordayacağı yönünde hipotez kurulmuştur. Fakat dindarlık, organ bağışı tutumunu pozitif yönde anlamlı düzeyde yordamıştır. Dindarlık, organ bağışı tutumunun \%9'unu açıklamıştır. Bilgi sahibi olma değişkeni de organ bağışını anlamlı düzeyde pozitif yönde yordamıştır. Bilgi sahibi olma, organ bağışının \%6.5'ini açıklamıştır. ${ }^{52} \mathrm{Bu}$ çalışmada, dindarlığın organ bağışını pozitif yordaması, literatürün tersine bir durum göstermiştir. Fakat bedensel bütünlük ile organ bağışı arasındaki regresyon ilişkinin negatif olması bize bazı ipuçlarını vermektedir. Bu çalışmanın Tablo 3'teki bulgularında; bireysel dindarlık, organ bağışının olumlu yönünü pozitif yönde açıklama etkisi göstermişken, organ bağışının olumsuz yönlerine dair herhangi bir etki sahibi değildir.

\section{Sonuç}

$\mathrm{Bu}$ çalışmada cinsiyete göre organ bağışı tutumlarının olumsuz tarafını temsil eden bedensel yaralanma korkusu boyutunda erkeklerin kadinlardan daha fazla ortalama puana sahip olduğu görülmüştür. Erkekler, organ bağışı tutumlarına kadınlardan daha fazla olumsuz yaklaşmaktadır. Cinsiyete göre dini ibadet konusunda kadınların lehine bir durum ortaya çıkmıştır. Kadınlar, erkeklerden daha fazla dini ibadete yönelmiştir. Korelasyon ilişkilerine bakıldığında organ bağışı tutumu ölçeğinin yardımseverlik ve ahlak/inanç değerleri boyutuyla tıbbi ihmal korkusu ve bedensel yaralanma korkusu arasındaki negatif yönde, bireysel dindarlıkla ise pozitif yönde ilişkisi vardır. Dini ibadet

52 Arisal - Atalar, "Influence of knowledge, bodily integrity, religion and media on attitudes toward organ donation on the university campus", 1647. 
ile çalışmanın temel değişkenleri arasında istatistiki olarak anlamlı düzeyde ilişkiler olmadığı tespit edilmiştir. Regresyon ilişkilerine bakıldığında ise dini ibadet, organ bağışı tutumunun alt boyutlarını yordamamıştır. Bireysel dindarlık ise organ bağışı tutumu ölçeğinin sadece yardımseverlik ve ahlak/inanç değerleri boyutunu yordamıştır. Organ bağışı tutumunun pozitif yönünü oluşturulan yardımseverlik ve ahlak/inanç değerleri boyutu, tıbbi ihmal korkusu ve bedensel yaralanma korkusu boyutunu negatif yönde yordamıştır. Bu çalışmanın bulgularına göre bireysel dindarlık ile organ bağışı tutumunun ahlaki, dini ve pro-sosyal yönünü oluşturan yardımseverlik ve ahlak/inanç değerleri boyutu arasındaki ilişkinin önemli olduğunu söylemek mümkündür.

\section{Kaynakça}

Arisal, Ibrahim - Atalar, Tarik. "Influence Of Knowledge, Bodily Integrity, Religion and Media On Attitudes Toward Organ Donation on The University Campus". International Journal of Nonprofit and Voluntary Sector Marketing 25/1 (23 Şubat 2020), e1647. https://doi.org/10.1002/nvsm.1647.

Ayten, Ali. “Din ve Sağlık: Bireysel Dindarlık, Sağlık Davranışları ve Hayat Memnuniyeti İlişkisi Üzerine Bir Araştırma". Dinbilimleri Akademik Araştırma Dergisi 13/1 (01 Şubat 2013), 7-31.

Ayten, Ali. "Kimlik ve Din: İngiltere'deki Türk Gençleri Üzerine Bir Araştırma". Çukurova Üniversitesi Illahiyat Fakültesi Dergisi (ÇüIFD) 12/2 (01 Haziran 2012), 101-119.

Ayten, Ali - Korkmaz, Sezai. "The Relationships Between Religiosity, Prosociality, Satisfaction With Life And Generalised Anxiety: A Study On Turkish Muslims". Mental Health, Religion and Culture $22 / 10$ Kasım 2019), 980-993.

https://doi.org/10.1080/13674676.2019.1695246.

Bodur, Hüsnü - Korkmaz, Sezai. “İlahiyat Öğrencilerinde Sosyal Medya Kullanımı ve Dindarlık İlişkisi". Kahramanmaraş Sütçü İmam Üniversitesi IIlahiyat Fakültesi Dergisi 30 (2017), 329-351.

Burra, P. vd.. "Changing Attitude to Organ Donation and Transplantation in University Students During The Years of Medical School in Italy". Transplantation Proceedings 37/2 (1 March 2005), 547-550. Elsevier USA, 2005. https://doi.org/10.1016/j.transproceed.2004.12.255. 
514 I S. KORKMAZ / Organ Bağışı Tutumları ve Dindarlık İlişskisi

Can, Fatma. "Organ Bağışında Aile Onayı Üzerine Bir Gözden Geçirme”. Nesne-Psikoloji Dergisi 5/09 (2017), 131-149.

Demir, Sıla - Sakallı-Uğurlu, Nuray. "Ölüm Belirginliği ve Yardım Hatırlatıcısı ile Organ Bağışını Teşvik Etme”. I. Sosyal Psikoloji Kongresi. 431-446. Ankara: Başkent Üniversitesi, 2016.

Diyanet İşleri Başkanlığı. Türkiye'de Dini Hayat Araştırması (Religious Life Survey in Turkey). Ankara: Tüik, 2014.

Güder, Emel vd.. "Attitudes and Behaviors Regarding Organ Donation: a Study on Officials of Religion in Turkey". Journal of Religion and Health 52 (2013), 439-449. https://doi.org/10.1007/s10943-011-9490-8.

Gürler, Hesna - Topal Hançer, Ayşe. "Bir Aile Sağlı̆̆ı Merkezine Başvuran Bireylerin Organ Bağışı Konusundaki Tutumları". Turkiye Klinikleri Journal of Medical Ethics-Law and History 28/1 (2020), 90-98. https://doi.org/10.5336/mdethic.2019-71012.

Irodat. "Donation 102 Countries Reported since 1996". DTI. 2020. Erişim 27 Haziran 2020.

https://www.irodat.org/?p=database\&c=TR\&year=2019.

Keçecioğlu, N. vd.. "Attitudes of religious people in Turkey regarding organ donation and transplantation". Transplantation Proceedings 32/3 (May1s 2000), 629-630. https://doi.org/10.1016/S00411345(00)00923-4.

Kent, Bridie - Owens, R. Glynn. "Conflicting attitudes to corneal and organ donation: a study of nurses' attitudes to organ donation". International Journal of Nursing Studies 32/5 (1995), 484-492. https://doi.org/10.1016/0020-7489(95)00009-M.

Korkmaz, Sezai. “Dindarlık ile Ego Sağlamlığı ve Empati Arasındaki İlişkilerin İncelenmesi". Bilimname 2018/2 (31 Ekim 2018), 587-607. https://doi.org/10.28949/bilimname.439858.

Korkmaz, Sezai - Mehmedoğlu, Ali Ulvi. “Dindarlık, Siber Zorbalık ve Problemli İnternet Kullanımı İlişkisine Dair Nicel Bir Araştırma". Dini Araştırmalar 21/53 (15 Haziran 2018), 35-54. https://doi.org/10.15745/da.433507.

Krupic, Ferid. "The Impact of Religion and Provision of Information on Increasing Knowledge and Changing Attitudes to Organ Donation: An Intervention Study". Journal of Religion and Health 58/3 (14 Aralik 2019), 1-14. https://doi.org/10.1007/s10943-01900961-0.

Krupic, Ferid vd.. "The Influence of Age, Gender and Religion on 
S. KORKMAZ / The Relationship between Organ Donation Attitudes and Religiosity I 515

Willingness to be an Organ Donor: Experience of Religious Muslims Living in Sweden". Journal of Religion and Health 58/3 (2019), 847-859. https://doi.org/10.1007/s10943-018-0670-7.

Linden, Peter K. "History of Solid Organ Transplantation and Organ Donation". Critical Care Clinics 25/1 (2009), 165-184. https://doi.org/10.1016/j.ccc.2008.12.001.

Özbolat, Abdullah. "'Organlarımla Dirilmek İstiyorum.'- Organ Bağışının Dini-Toplumsal Arkaplanı". Çukurova Üniversitesi Illahiyat Fakültesi Dergisi (ÇÜIFD) 17/1 (30 Haziran 2017), 61-87. https://doi.org/10.30627/cuilah.326050.

Parisi, N. - Katz, I. "Attitudes toward posthumous organ donation and commitment to donate". Health psychology: official journal of the Division of Health Psychology, American Psychological Association 5/6 (1986), 565-580. https://doi.org/10.1037/0278-6133.5.6.565.

Randhawa, G. - Neuberger, J. "Role of Religion in Organ Donation Development of the United Kingdom Faith and Organ Donation Action Plan". Transplantation Proceedings 48/3 (01 Nisan 2016), 689694. https://doi.org/10.1016/j.transproceed.2015.10.074.

Ríos, A. vd.. "Do Religious Factors Influence the Attitude Toward Organ Donation Among Medical Students? A Spanish Multicenter Study". Transplantation Proceedings 51/2 (01 Mart 2019), 250-252. https://doi.org/10.1016/j.transproceed.2018.11.003.

Ryckman, Richard M. vd.. "Intrinsic-Extrinsic Religiosity and University Students' Willingness to Donate Organs Posthumously". Journal of Applied Social Psychology 34/1 (01 Ocak 2004), 196-205. https://doi.org/10.1111/j.1559-1816.2004.tb02544.x.

Uysal, Veysel. "Gençlerde Empati, Anne-Baba Tutumları ve Dindarlık". Dokuz Eylül Ünivesitesi İlahiyat Fakültesi Dergisi-Din Psikolojisi Özel Say1s1 (15 Nisan 2016), 7-40. https://doi.org/10.21054/deuifd.282803. Wakefield, Claire E. vd.. "Religious and ethnic influences on willingness to donate organs and donor behavior: An Australian perspective". Progress in Transplantation 21/2 (01 Haziran 2011), 161-168. https://doi.org/10.7182/prtr.21.2.2071rgn834573152.

www.irodat.org. International Registry In Organ Donation and Transplantation. Barcelona, 2020. 1-16. www.irodat.org.

Yalçın Balçık, Pınar vd.. “Üniversite Öğrencilerinin Organ Bağışına ve Nakline Yönelik Tutumları". SDÜ Sağlık Bilimleri Dergisi 10/3 (20 Eylül 2019), 314-319. https://doi.org/10.22312/sdusbed.568312. 
516 | S. KORKMAZ / Organ Bağışı Tutumları ve Dindarlık İlişkisi

Yapıcı, Asım. Türk Toplumunda Cinsiyete Göre Dindarlık Farklılaşması: Bir Meta-Analiz Denemesi. Fırat Üniversitesi İlahiyat Fakültesi Dergisi 17/2 (2012), 1-34.

Yazici Sayin, Yazile. "Turkish validity and reliability of Organ Donation Attitude Scale”. Journal of Clinical Nursing 25/5-6 (01 Mart 2016), 642-655. https://doi.org/10.1111/jocn.12943.

Zagumny, M. J. vd.. "Psychometric analysis of the Religious Identity Index". Presentation at the 24th Annual Convention of the Association for Psychological Science. 107. (May 2012). 